\title{
Dairy farm systems to aid persistence
}

\author{
K.A. MACDONALD ${ }^{1}$, C. MATTHEW ${ }^{2}$, C. B. GLASSEY ${ }^{1}$, and N. MCLEAN ${ }^{3}$ \\ ${ }^{1}$ DairyNZ, Private Bag 3221, Hamilton \\ ${ }^{2}$ Institute of Natural Resources, Massey University, Private Bag 11-222, Palmerston North \\ ${ }^{3}$ Agricultural Business Associates, Box 14-170, Hamilton. \\ kevin.macdonald@dairynz.co.nz
}

\begin{abstract}
This manuscript reviews fundamental pasture management principles relevant to pasture persistence. We first note some points of context, within which the debate on pasture persistence is occurring: the release of new pasture cultivars, the debate about climate change, and the effects of newly introduced weeds and pests. We then examine trends in farm practice. The critical management period (of most concern to farmers) has shifted from winter/autumn to summer. It is essential that farmers have and use sets of decision rules to govern when and how hard to graze, when to supplement and when to remove cows from pasture to allow pastures to be grazed appropriately to aid pasture persistence. Adaptations available to improve pasture persistence include: the use of nitrogen fertiliser to increase feed supply going into the summer, the use of crops or other feed supplements, stocking rate and on-off grazing to ensure the pastures are appropriately grazed in the summer. New pastures must be treated with care in their first year of life to ensure survival. The response of farmers to these variables to aid persistence of pastures is discussed.
\end{abstract}

Keywords: climate, insect pests, pasture growth model, pasture renewal, weeds

\section{Introduction}

The dairying area of New Zealand is approximately 1.45 million hectares of improved pastures, some possibly without pasture renewal for approximately 150 years. Sanderson \& Webster (2009) reported that just over 6\% of dairy pastures are renewed each year. They calculated that if pasture renewal gave a production response of 7 $-27 \%$ this could potentially increase dairy farming's contribution to Gross Domestic Product by up to $\$ 220$ million per annum.

Pasture eaten has increased from $4 \mathrm{t}$ to $11.7 \mathrm{t} \mathrm{DM} /$ ha/yr from 1935 (Holmes 1989) to 2007 (Rawnsley et al. 2007). Recent estimates from high performing New Zealand dairy farms show pasture eaten to be 15-17.5 t DM/ha/yr (Holmes 2007; Glassey 2007; Macdonald et al. 2008b). For at least 20 years, this increase in pasture eaten has been attributed to pasture renewal (Edgecombe 1988). Despite initial increases in pasture yield, renewed pasture in some regions of
New Zealand is often re-sown within 5 years due to low productivity and poor persistence of grasses such as perennial ryegrass (Lolium perenne) (Bell et al. 2009). The cost of pasture renewal is between $\$ 600$ and $\$ 3600 /$ ha depending on the method used and any cropping included (Bryant et al. 2010a). Thus, the cost is considerable and farmers need to see an advantage (lasting longer than 5 years) otherwise they are unlikely to consider pasture renewal.

An important determinant of pasture persistence is the interaction between the plant itself, the environment, and pasture management. From this perspective, potential causes of poor pasture persistence include:

- Plant genetic factors - there is a perception among farmers that selection for increased yield in modern cultivars may impact negatively on some aspects of field performance;

- Climate - for example, higher frequency and duration of moisture deficit;

- Management - for example, more severe grazing events (particularly during critical periods in the first establishment year);

- On-farm changes affecting the plant environment. For example, dairy farm stocking rates have generally increased over the last 30 years, leading to a number of changes affecting pastures, including increased risk of treading damage and increasing soil compaction over time.

In this paper, the impacts of management on pasture persistence are reviewed and recommendations given. Some other points such as cultivar effects, climate, and weeds and pests are also briefly discussed.

\section{Cultivar and persistence}

The history of ryegrass cultivar development in New Zealand has been well summarised by Stewart (2006). Briefly, early ryegrass cultivar releases from DSIR Grasslands such as Grasslands Ruanui were largely genetically derived from persistent Hawkes Bay ecotypes. From the 1970s onward, beginning with the cultivar Grasslands Nui, and a parallel release by a private company of the cultivar 'Ellett', many ryegrass cultivars have been genetically based on a 'Mangere' ecotype sourced from a farm in South Auckland owned by Mr Trevor Ellett. Cultivars based on the Mangere 
ecotype consistently out-yielded their predecessors by $10 \%$ or more in formal trials. For example Bahmani et al. (2001) compared Grasslands Ruanui with Ellett (a selection from the Mangere ecotype) at Ruakura for 2 years and recorded a $13 \%$ annual DM yield advantage to Ellett over Ruanui. Anecdotal farmer perception was that Grasslands Nui and Ellett were persistent, although Thom et al. (1996) suggested that some of the cultivars derived from this original selection are more susceptible to pulling and plants in peat soils are more at risk than those in silt loams.

In the last two decades there have been a number of notable developments, including among others: (i) the use of genetic material collected from NW Spain in some cultivars (e.g. Tolosa, One50), (ii) infusion of fescue genetic material in some cultivars (e.g. Matrix, Revolution) (Stewart 2006) and (iii) introduction of novel endophytes such as AR1 and AR37. The value of novel endophytes in terms of plant protection by improving plant performance is well established (Popay $\&$ Thom 2009).

A difference of opinion exists as to the performance of the currently available perennial ryegrass cultivars relative to established permanent pastures. One opinion points out that top yielding modern varieties consistently out-yield Grasslands Nui (expected to have similar performance to Ellett, mentioned above) by a further $10 \%$ in company trials (G.A. Kerr, New Zealand Agriseeds, personal communication) and have higher feeding value than older varieties (Woodfield $\&$ Easton 2004). The yield trials ran for only 3 years, but those conducting them do not report any visible loss of plant density or yield within that time. If this is the case then it would appear that perceived persistence problems should not be attributed to poor plant genetics.

Another opinion represented by Parsons et al. (2010) refers to a particular trial that showed no statistical difference in yield between perennial ryegrass cultivars with a 20 -year difference in release date and maintains that this result should be accepted as a basis for future action. Meanwhile many anecdotal reports exist of recent pasture sowings not performing well. There have been few studies which follow the performance and fate of modern cultivars to distinguish between the various causes of loss of yield (Parsons et al. 2010). These causes could include: decline in the population of a newly sown species, a reduction in numbers of individuals within a population that express the trait of interest, or a loss of yield not related to the properties of the population itself. For example, the latter could occur when an initial advantage from $\mathrm{N}$ mineralisation following tillage tails off (Parsons et al. 2010).

\section{Is the climate changing and if so is this relevant?}

In the last 3 years there have been serious droughts in the Northern part of the North Island. At these times, soil moisture deficit has been 125 to $150 \mathrm{~mm}$ or greater for extended periods putting stress on the plants. After this, farmers have reported that pastures are in need of re-sowing but it is unclear if the sward deterioration observed is due to drought per se or a combination of factors.

One opinion is that the perceived increase in frequency of drought events is an early sign of anthropogenic climate change and that the supposed trends can be expected to continue. Many authoritative sources maintain changes such as increasing atmospheric carbon dioxide concentration are contributing not only to an overall warming trend but also a greater frequency and intensity of drought and storm events (IPCC 2010). However, such assertions remain contentious and hotly debated.

However, the key point about weather perturbations such as the dry summers occurring recently across several regions including Gisborne, Waikato, and Northland is not their cause, but rather that whenever there is a drought, pastures are stressed and weakened. There is also a perception that extreme weather events facilitate the arrival and spread of annual grass weed species (e.g. Setaria species such as yellow bristle grass and Axonopus, among others). These grasses seem to be better adapted than ryegrass to warm summer conditions and fluctuations in climate, and also germinate easily from seed set (Campbell et al. 1996). The conclusion to be drawn from these points, then, is that despite many decades of research we still have an incomplete knowledge of the tolerance of perennial ryegrass to climate perturbation and of the interactions between ryegrass and competitor species.

\section{Weed and pest invasion}

Insects such as Argentine stem weevil (ASW) (Listronotus bonariensis), black beetle (Heteronychus arator), grass grub (Costelytra zealandica), clover root weevil (Sitona lepidus), white-fringed weevil (Naupactus leucoloma) and Australian soldier fly (Inopus rubriceps) are all having an impact on ryegrass and clover plant survival. Popay \& Thom (2009) reported that the introduction of AR37 (an endophyte) into ryegrass had a significant positive effect on plant survival compared with plants without this endophyte due to reduced insect pressure.

Farmers face the problem of maintaining new ryegrassbased pastures with desirable novel endophytes. Earlier work by Thom et al. (1999) identified that new pastures are at risk from re-contamination with plants containing the old endophyte if a poor method of establishment 
is used. Another cause of poor persistence is the use of seed stored for long periods ( $>6$ months) at high temperatures and humidity. During seed storage the level of viable endophyte in the seed reduces (Rolston et al. 1991) so using seed left over from last year should be avoided.

Where pasture plants die and bare ground is present, the gaps that appear can act as a place for the invasion by annual weed species (Panetta \& Wardle 1992). Once established, these weeds will then tend to suppress or prevent reseeding or tillering from ryegrass. Thus it is essential that the pasture is managed in such a way to minimise bare ground appearance.

It is often suggested that a mix of cultivars and species be sown to avoid a single pasture species (e.g. ryegrass) as it may be more at risk to stresses from insects and dry periods. Suggested ways to alleviate this issue are to sow a mixed or multi-species pasture (Musgrave \& Daly 2004; Musgrave 2011, this volume) with traditional ryegrass clover pastures. But each plant species has its own 'best' conditions. For ryegrass it is cool moist conditions, whereas tall fescue can withstand higher summer temperatures but grazing management requirements also differ. This adds a complexity for farmers in trying to decide what to sow when they want a mixed species pasture, but Musgrave \& Daly (2004) suggested it can be economic to do so.

An establishment practice (Programmed Approach ${ }^{\mathrm{TM}}$ ) suggested by Lane et al. (2009) incorporates cropping to break the weed/pest cycle to give the new plants an increased chance of survival. The programme involves planning well ahead of the event, such that additional fertiliser, liming, spraying with glyphosate etc. can be done before the soil is ploughed. Then, there is a programme of sowing a summer crop with the control of weeds and pests, an autumn spray after the summer crop to clean out any residual weeds before autumn sowing of the new perennial pasture. The new pasture must have adequate levels of fertiliser and in particular sufficient $\mathrm{N}$ as the new clovers need $\mathrm{N}$ as well as the grasses and will not fix much $\mathrm{N}$ in the first 12 months.

\section{Management of the plant}

Grazing management recommendations must take account both of effects on sward persistence and sward production. Theoretically, persistence depends on maintenance of the plant or shoot population and hence for a grass sward, persistence can be defined in terms of the balance between tiller birth and death. Any factor causing a small increase in death rate or decrease in birth rate of tillers can act over time in a manner akin to compound interest (Matthew \& Sackville Hamilton 2011). This insight provides a guiding principle for identifying safe periods and danger periods.

With respect to the birth and death of ryegrass
Figure 1 Theoretical tiller numbers needed for light capture at different herbage masses in summer and winter. Winter and summer lines show herbage mass/tiller density combinations theoretically required for light capture at low light in winter and high light in summer, respectively. ${ }^{1}$

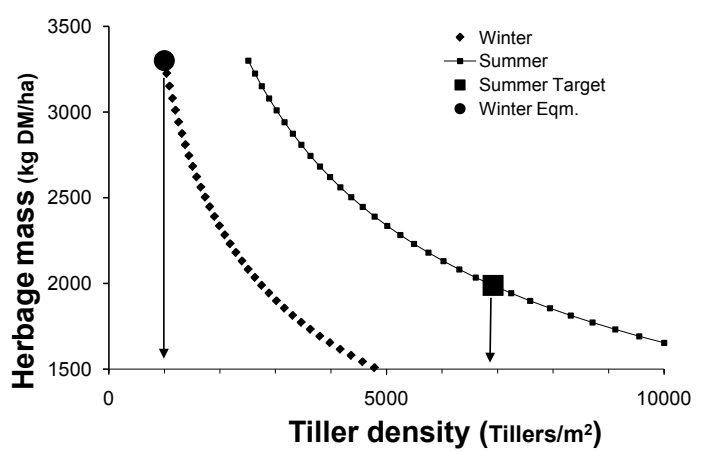

1 The starting point was an assumption of a winter equilibrium tiller density (Winter Eqm.) of 1,000/ $\mathrm{m}^{2}$ at $3300 \mathrm{~kg} \mathrm{DM} / \mathrm{ha}$ pregrazing herbage mass. If pre-grazing herbage mass in a summer feed deficit falls to $2000 \mathrm{~kg} \mathrm{DM} / \mathrm{ha}$ and light levels in summer are $2.5 x$ those in winter, then the summer tiller density theoretically required for light capture is approximately 7,000 tillers $/ \mathrm{m}^{2}$. The diagram indicates that not protecting post-grazing residuals in summer theoretically places tillers under more stress. Arrows indicate the tiller density shift theoretically required to maintain a constant sward leaf area index.

tillers, the winter is usually a safe period. Moist cool conditions mean tiller death rates will be low, and swards will be forgiving of stress factors like close grazing. An exception to this principle is when winter grazing involves high animal grazing days per hectare in conditions of high soil moisture, leading to treading damage. In spring, tillers begin to flower, and the flowering tillers die after flowering and also create shading and nutrient withdrawal stresses for smaller neighbouring tillers. In summer, moisture deficit is common and afternoon soil surface temperatures can exceed $30^{\circ} \mathrm{C}$ - well outside the optimum for growth of around $20^{\circ} \mathrm{C}$ for ryegrass and $24^{\circ} \mathrm{C}$ for white clover (Mitchell 1956). Based on these factors, we refer below to three grazing management seasons when defining how to manage swards for persistence: autumn/winter, spring (early and late spring), and summer.

With respect to herbage production, it is widely known that pasture tiller density increases in response to decreased sward height and vice versa (Kay \& Harper 1974; Davies 1988; Matthew et al. 1996). However, the flow-on effects for productivity of that fundamental population response have been less well understood over the years and paradoxically it is usually the case when comparing contrasting defoliation treatments in a controlled experiment that a higher tiller density resulting from either a lower grazing residual or a shorter grazing interval is associated with a lower 
sward leaf area index (Hernández Garay et al. 1999).

Sward leaf area index and population dynamics also need be considered in the context of leaf turnover. Each leaf produced by a grass plant has a bud at the base capable of developing a new tiller. A vast majority of these buds are never used, but they are activated by light reaching the sward base (Casal et al. 1987), so that either a lower residual grazing height or more frequent grazing will result in more of these buds receiving enough light to stimulate growth (Matthew et al. 2000). Conversely, a longer grazing interval may result in some smaller tillers dying from shading and a fall in tiller density. Basically, the tillering response after a severe grazing is an attempt by the grass sward to regain leaf area lost under the increased grazing pressure, whereas the death of tillers in long swards merely eliminates weaker tillers no longer needed. However, for herbage mass levels typically found on farm, when comparing swards at different positions on a grazing intensity continuum, the sward leaf area under a short, higher tiller density sward is less than the leaf area of a more leniently or less frequently defoliated low tiller density sward in the same conditions. This is because the new tillers produced at lower herbage mass generally only partly replace the leaf area (and energy) lost when swards at higher herbage mass are defoliated (Matthew et al. 2000). This expectation of increased leaf area index of longer swards applies both when new tiller bud release is stimulated by light penetration in shorter swards and when small tillers are killed by shading in longer swards, although there is an upper limit to the herbage mass at which leaf area continues to increase with increasing herbage mass (Matthew et al. 2000). The herbage mass beyond which productivity declines was found to be around $2500 \mathrm{~kg}$ $\mathrm{DM} /$ ha for perennial ryegrass dominant dairy swards in New Zealand in winter (Bluett et al. 1998).

Design and interpretation of experiments to test the outcomes of differing grazing management regimes is complicated by the need to distinguish between vegetative growth responses and flowering phase responses. For vegetative swards, a grazing interval based on leaf regrowth stage has been shown to optimise the persistence, production, utilisation and quality of temperate pasture species (Donaghy et al. 2008; Fulkerson \& Donaghy 2001; Rawnsley et al. 2002). There is sound reasoning behind this principle, as a grazing interval for perennial ryegrass occurring between the two- to three-leaf regrowth stage allows for replenishment of plant energy reserves and provides an adequate balance of herbage minerals for cows; avoids plant senescence/wastage and herbage quality decline; and captures the most rapid growth phase of the plant (Fulkerson \& Donaghy 2001). Whereas, shorter grazing intervals ( $<$ two leaves) reduce regrowth and persistence, and can result in imbalanced mineral levels. Grazing intervals > three leaves, or canopy closure will reduce pasture quality due to an increase in dead material in the sward and also persistence due to reduced tiller density. Tools for farmers to implement the two-three leaf principle include rotation length planning (e.g. Spring rotation planner), and use of supplements to ensure animals are adequately fed.

Using the three-leaf principle, Lee et al. (2008) demonstrated that severe grazing (residual height $<3$ $\mathrm{cm})$ reduces pasture regrowth and can reduce plant persistence due to removal of plant energy reserves. Also, lax grazing (residual height $>6 \mathrm{~cm}$ ) reduces the herbage quality of the feed on offer and while regrowth may not be affected in the short term, subsequent lax grazing will result in a less productive and a less persistent pasture (Lee et al. 2008), possibly through shading of small tillers. In early Spring 1500-1600 $\mathrm{kgDM} / \mathrm{ha}$ is about 3.5 to $4.0 \mathrm{~cm}$ height (7-8 clicks on the rising plate meter; RPM) but in late Spring at the same height it rises to $1800-2000 \mathrm{kgDM} / \mathrm{ha}$.

Consideration of seasonal herbage mass changes likely to occur in response to the shifting balance between pasture growth and animal intake is also relevant to understanding sward tiller density responses. On spring calving dairy farms, pasture covers tend to fall for 60 days from the start of calving. Herbage mass typically increases again in spring before declining going into summer, meaning that the development of new tillers will be triggered and that paradoxically the sward leaf area will fall at a time of increasing light level. Fig. 1 shows herbage mass/tiller density combination that theoretically provides a leaf area for light capture at low light and higher cover in winter and also higher light and lower cover in summer. It shows that tiller density needs to more than double from winter to summer to maintain full light capture. The logical conclusion is that spring grazing should avoid extremes of high and low herbage mass because summer tiller density and herbage quality may be depressed following high spring herbage mass, while summer leaf area index may be depressed as a consequence of low spring herbage mass. In one experiment designed to test these principles in a dairy farm context, grazing management that promoted higher average herbage mass in spring was linked to increased spring and summer herbage production and cow milksolids production, but with a tendency to reduced sward clover content and lower herbage nutritive value partially offsetting the summer herbage production gain (Da Silva et al. 2004).

The size/density compensation response described above, whereby comparatively laxly grazed swards are expected to have a lower tiller density but higher 
leaf area index, should be distinguished from sward thinning, the reduction in tiller density that arises when factors other than shading accentuate the tiller death rate. This occurs, for example, where a sward is losing tillers to insects such as Argentine stem weevil or through death from reserve depletion as a result of overgrazing. Ironically, high tiller death from overgrazing is often preceded by an initial increase in tiller density from the size/density effect as herbage mass falls, and gaps in the sward from death of tillers may be filled with clover, temporarily improving animal performance.

The formulation of advice about optimal summer grazing management is further compounded by the fact that a standard response to diminishing feed supply in summer drought is to lengthen the rotation, and thereby reduce pasture intake by animals. This necessarily results in lowering the residual after grazing. In winter it is a well-established practice to limit intake using a long rotation, and the resulting lower residual herbage mass after grazing appears to be tolerated reasonably well by swards in the cool, moist conditions prevailing, so long as treading damage does not occur. However, it is not at all clear that a short grazing residual is tolerated by swards in summer as it is in winter. In drier, warmer summer conditions a lower residual herbage mass after grazing necessarily indicates increased depletion of sward leaf area and likely also indicates accentuation of stress on tiller bases and their leaf elongation zones. Hence, in summer there is the possibility of an extended period of slow regrowth after a close grazing. The experiments of Brougham $(1957,1960)$ appear to confirm these different seasonal responses to defoliation intensity. In the summer therefore, the drive to have a longer rotation length must be combined with retaining a similar post-grazing residual throughout the rotation length transition.

As well as grazing height being important, grazing duration is also important. Grazing of the same area should not exceed a period of 48 hours, as exceeding this will result in depletion of plant energy reserves, affecting regrowth and plant persistence (Fulkerson \& Donaghy 2001). If cows are grazed in paddocks for more than 2 days, a back fence should be used to prevent them from re-grazing the previous area.

The clover content of the sward also has to be considered. As mentioned above, perennial ryegrass has an optimum temperature for growth of around $20^{\circ} \mathrm{C}$ while the optimum for white clover is around $24^{\circ} \mathrm{C}$. The appearance of bare ground increases soil temperature and reduces plant survival. Historically, New Zealand swards have had a comparatively high clover content, with the proportion increasing in summer and decreasing in winter. In recent years there has been a perception, particularly in dairy pastures, that increased use of $\mathrm{N}$ fertiliser and other factors such as higher stocking rates or greater incidence of insect pests have reduced clover content of swards. If this is so, the possibility for increased clover growth to compensate for decreased ryegrass growth in summer may be reduced. Confirmation by objective measurement of clover performance in modern pastures would be useful.

Newly sown pastures need to be treated to ensure that there is good establishment. Management in the first year of the plant's life will have a major influence on its survival chances. Lack of sufficient $\mathrm{N}$ for the plant, hard grazings and making conservation from the pasture will all weaken the plant or reduce plant numbers and thus the viability of the sward.

\section{Managing the system}

To combine insights from sward tiller dynamics theory, component and paddock-scale research on leaf turnover, and the seasonal differences in the respective responses and to integrate these principles for application at the farm level, grazing management recommendations need to be formulated separately for the three key seasonal periods identified above: autumn-winter, spring, and summer.

\section{Autumn/winter management}

On most dairy farms the primary objective of autumn/ winter management is to achieve a desired average farm herbage mass at calving of 2200-2400 kg DM/ha (Bryant 1990). This will depend on stocking rate and date of calving relative to when pasture growth will exceed herd requirements. Most pasture damage related to persistence that occurs during the winter is through pugging which can have flow on effects on grazing intensity for several months (Ledgard et al. 1996). During wet periods, stand-off areas such as laneways or feed pads should be used to maintain a longer rotation and ensure pasture damage is limited.

\section{Spring management}

In early spring, grazing interval should be greater than 14 days as a short rotation increases pasture intake and decreases pasture growth, reducing the ability of pasture growth rate to support feed demand. Bryant \& L'Hullier (1986) compared fast (8-14 days), with slower ( $>30$ days) inter-grazing intervals in late winter. The farmlet on the faster rotation had less feed from September to December than the slow rotation group due to the reduced pasture growth rate. The use of a spring rotation planner (Macdonald \& Penno 1998) will ensure that grazing rotation does not become too fast and the use of supplements can ensure the desired postgrazing residuals and feeding levels for the cows. 
Later in spring, once pasture growth exceeds herd requirements, surplus pasture must be removed from the grazing area to maintain appropriate postgrazing residuals, pasture quality and subsequent milksolids production. At the same time the herd must be generously fed to maximise MS production, and meet reproductive performance objectives. To ensure pasture quality is maintained, and the herd properly fed, surplus pasture is identified and harvested according to a formula (or set of decision rules) described by Macdonald \& Penno (1998).

During spring when pasture is growing rapidly, and particularly if comparatively high rates of nitrogen fertiliser are applied ( $>60 \mathrm{~kg} \mathrm{~N} / \mathrm{ha} /$ application), canopy closure of the sward may occur before the $2 \frac{1}{2}$ leaf stage of regrowth. During this period, the grazing interval may need to be reduced, although if canopy closure is consistently occurring before $2 \frac{1}{2}$ leaves, the first response should be to reduce the amount of $\mathrm{N}$ fertiliser applied, rather than to speed up the rotation (Staines \& Morris 2008).

The use of topping (mowing pre or post-grazing) is often advocated as a way to control the feed quality, but L'Hullier \& Aislabie (1988) identified that topping to remove reproductive tillers before flowering will greatly reduce ryegrass reseeding and may contribute to the poor persistence of ryegrass swards under intensive dairy cattle grazing. Thus it may be necessary to ensure that topping is stopped before the majority of the reproductive tillers are present to give the pastures a chance to reseed. Clumps left in a paddock do not necessarily signal poor pasture management, but the fact that cow requirements and pasture cover were not matched for that day. Regardless, there is still a need to consistently achieve an even grazing height (7-8 clicks on the RPM).

\section{Summer management}

During the early summer, average pasture mass is generally high as pasture growth has exceeded requirements for the preceding months. At the same time pasture growth rates are declining due to lower soil moisture availability. Extending rotation length (grazing interval) from a short (16 day) to a long (30 day) rotation reduces herbage allowance and forces the herd to graze to target post-grazing residuals and remove all available pasture (Penno et al. 1995).

Anecdotal evidence from farmers is that new ryegrass cultivars with novel endophytes are more 'cow friendly' to the extent that cows will graze these cultivars harder than some of the older cultivars with wildtype endophyte. Although this is beneficial in terms of immediate pasture management, long term it may be detrimental as there is risk of overgrazing reducing the life expectancy of the plant. To overcome this, farmers must have in place systems to ensure that overgrazing does not occur, such as on-off grazing or the removal of the cows from the pasture when the desired residual has been achieved. A recent grazing trial conducted in spring and autumn (Clark et al. 2010) demonstrated that on-off grazing can be a successful method to reduce overgrazing of pasture whilst maintaining intake and production. On-off grazing is generally only considered by farmers to reduce pugging in wet periods but these results suggest it could be a useful tool for grazing management during summer and autumn. It is essential that decision rules are developed around this practice that enable plant survival by ensuring overgrazing does not occur at critical times of the year such as summer.

\section{Management tools}

\section{Supplements}

There has been an upsurge in the use of supplements as a strategy for bridging shortfalls between pasture growth and animal demand. Initially, only maize silage was used but other options have now become available, one being palm kernel expeller (PKE). In 2005 approximately 188,000 tonnes were imported and this has increased to $1-2$ million tonnes for 2010 . The use of supplements has to be planned and systems need to be in place to ensure that the supplement and pasture are utilised efficiently. This may mean the use of an appropriate feeding system or standoff area to reduce overgrazing.

When using supplementary feeds there is a conflict between feeding the cows and still ensuring the system is economic. As demonstrated in the trial that targeted and achieved a production level of $1.75 \mathrm{t} \mathrm{MS} / \mathrm{ha}$ (Macdonald 1999), the use of purchased feed can be uneconomic and accepting a lower level of production may be more economic than using supplements. Software tools now exist to assist in planning supplement use (see below).

\section{Stocking rate and cow body size, breed and genetic merit}

From 1979 to 2009 the average stocking rate on New Zealand dairy farms increased from 2.1 to $2.8 \mathrm{cows} / \mathrm{ha}$ (LIC 1980, 2010). At the same time there was a breed change from Jersey to Friesian-Jersey cross cows with a resulting increase in cow average live weight from 390 to $460 \mathrm{~kg}$. This effectively has resulted in a $57 \%$ increase in live weight/ha. Cow genetic merit has also improved with a $20 \%$ increase in per cow production and larger more productive cows requiring higher feeding levels (Macdonald et al. 2008a). At the same time there has been a rapid expansion of farm size and of dairying on marginal dairy areas where pastures grow insufficiently to sustain these stocking rates, thus there is increased 
risk of overgrazing pasture during seasonal feed deficits or at other critical times. To compensate for the effect of increasing cow genetic merit and the resultant increase in feed demand, Montgomerie (2010) suggested that farmers reduce their herd size by $1 \mathrm{cow} / 150 \mathrm{cows} / \mathrm{year}$.

The first risk at any stocking rate is the amount and distribution of pasture production which is driven by climate. In most areas of New Zealand, (and reported specifically for Southland; Macdonald \& Hedley 2010a) there is large variability in daily pasture growth between years, particularly in the summer and autumn. Any variation in feed supply from the norm or expected must be planned for. The effects of shortfalls in feed supply are greater as stocking rate increases.

A series of trials in the 1980 s refined management practices for autumn/winter through to spring (Bryant \& L'Hullier 1986). Until then the major concern for farmers was generally around getting the cows through this period. The information from these trials gave farmers a knowledge of herd and pasture management requirements for effective winter management and this confidence has been a factor contributing to increased stocking rates. As a result the problem has shifted. The major concern for farmers now is how to get the herd through the summer with sufficient days in milk to give an acceptable economic return for the season as a whole.

Farmers need to calculate the feed requirements of the herd and ensure they have the appropriate stocking rate and number of cows to manage the system, realising that the critical period can be summer. This means systems need to be in place to allow for reducing herd demand by a reduction in milking frequency (once a day or $18 \mathrm{~h}$ milking interval for the whole or part of the herd) or de-stocking the farm by early removal of culls (Macdonald \& Penno 1998)

\section{Calving date and pasture growth}

Macdonald \& Hedley (2010b) demonstrated that pasture production in the Waikato in the spring and early summer is more consistent from year to year than late summer/autumn pasture production and this is probably the same for most areas of New Zealand. Therefore, maximising production up to late December is an important strategy in seeking to minimise the economic risk of low seasonal production during dry summers, particularly in the North Island. High production prior to Christmas can be achieved through a high stocking rate, or a moderate stocking rate and early calving. For either system, calving date varies regionally according to the timing of the spring pasture growth flush and there also needs to be a plan to manage a wet or late spring and/or a dry summer. Macdonald \& Hedley (2010b) gave some rules around calving date in relation to stocking rate. For example, highly stocked farms (pasture growth rate approximately equal to daily per ha. animal demand at peak lactation) with an all-grass system in the spring need to have a planned start of calving 50 days before balance date (when feed supply meets demand). If the farm has a moderate stocking rate then it should be 55-60 days, whereas if it has a low stocking rate it should be 60-70 days.

\section{Use of data bases}

DairyBase presents an opportunity to examine profitability trends when the amount of pasture renewal is considered. DairyBase uses the actual spending of contributing dairy farmers across the country. Providing that there are sufficient individual records it is possible to analyse for regional variations in profitability.

An analysis of the Waikato records was carried out for the 2007/2008 and the 2008/2009 seasons and the first observation that can be made is that farming systems that have moderate levels of supplementation (Systems 2 \& 3; as described by Hedley et al. 2006) appeared to have lower profitability than Systems 1, 4 and 5. Further analysis (DairyNZ 2010) demonstrated that it is not the system that determines the economics of a particular farm but how that farm is managed and the level of the operating expenses. The use of broughtin supplementary feed is very easy to monitor and cost. Hence, a lot of emphasis in extension circles has been focused on achieving efficient use of supplements. As the pressure to produce a profit from intensive farming systems increases, it is possible that there will be more emphasis on this rather than realising the benefits of new pasture combinations. The current perceptions about the lack of persistence of new pasture varieties may mean that pasture renewal will come under scrutiny as not being profitable, but it can be if there is planning and new pastures are managed to ensure they are not grazed severely and conservation is not made from them in their first year.

\section{Use of computer models}

One of the tools available to innovative farmers is the use of sophisticated farm computer models to analyse for opportunities. Models such as Farmax Dairy (Bryant et al. 2010b) can be used as a decision support tool to assist in balancing pasture intake, supplement use and pasture cover, with regard to financial outcome. The approach taken on-farm is to model performance over years so that a robust model of the farm is developed. With the benefit of hindsight it is possible to change the management inputs to the farm system. These changes will generate a change in farm outputs which will have a financial impact. The level of this impact can then be assessed to see if it is significant and the sensitivity of 
the decisions to the overall profitability of the farm is determined.

The model will allow the opportunity to ask "what if" questions of changing the management strategy at different times of the season.

Examples of these test questions include

- The impact of pasture quantity and quality at different times of the season

- The impact of different stocking rates

Thus the use of computer models will allow farmers to plan for the future enabling them to test a number of scenarios, being able to predict what will be financially successful and what will not. Using such tools, a growing number of farmers now stockpile sufficient supplements to give constancy of late summer production across years, regardless of summer rainfall, or employ irrigation if practicable.

DairyNZ has developed a model (PGSUS; Romera et al. 2010) that estimates pasture growth using climate data for up to 28 days, by learning from historic pasture growth rates. A model such as this could be a vital step in feed budgeting and assisting on-farm decision making as it is often considered too onerous to do weekly farm walks to assess pasture cover and, therefore, planning becomes a low priority.

\section{Uptake of on-farm research 'More summer milk'}

The 'More Summer Milk' trial (McGrath et al. 1998) reported that a late spring-application of nitrogen fertiliser to pasture was more profitable than the use of feed crops. It seems that the message from the work has not been implemented by farmers because the purchase of urea is a steady $10 \%$ of the cost of total purchases over most months. This indicates that farmers may not be planning to use extra $\mathrm{N}$ to increase feed supply for the critical summer period but just applying a set rate for most of the year.

Most dairy farmers are able to grow sufficient pasture in the spring to meet cow requirements, given reasonable weather conditions. The summer is the time when problems occur because of pasture shortages. Penno et al. (1995) identified the use of $\mathrm{N}$ in early summer as a method to ensure there was increased growth for the following 2 months and thus the ability to "protect" post-grazing residuals. Increased herbage mass allows for feeding the cows better and also ensures that postgrazing residuals are such that grazing height stays in the range of 7-8 clicks on the RPM.

\section{Summary and conclusions}

Methods are already available to ensure pasture persistence. Farmers need to plan and have systems in place to ensure that cows are adequately fed, but more importantly that pastures are not overgrazed. The use of supplements and/or removal of cows from the pasture at critical times to avoid overgrazing is essential. Farmers often only consider removing cows from pastures during wet periods to avoid pugging. This has to change as lack of moisture to the plant is more damaging to the plant than too much water. The critical management time of year used to be winter but with adoption of management practices based on trial studies this is less of an issue with dairy farmers and the critical period has been shifted into summer.

Another method available is the use of $\mathrm{N}$ in early summer to ensure higher pasture covers later in summer as this will "protect" summer post-grazing residuals.

Ensuring that the pastures sown are appropriate for the area and are protected from insect damage, through the use of endophyte, will help ensure the pastures establish and survive. It appears that plant losses and other perceived persistence problems should not be attributed to poor plant genetics. Lack of persistence may well be due to mismanagement of the pasture in the first year of its life from overgrazing, from allowing the sward too get too long by closing it for conservation, or from failing to observe desirable grazing residuals after grazing in summer dry spells.

Farm systems (supplement use), stocking rate and type of cow farmed have all changed over the last 20-30 years, along with an increase in the number of cows, particularly into marginal areas for dairying and the increase in stocking rate (and $\mathrm{kg}$ live weight per ha) with no increase in DM production. This all means that there is a need to implement management protocols to improve persistence of pastures. The use of a set of decision rules governing when and how hard to graze, when to supplement and when to remove cows from pasture are essential to develop persistent pastures and ensure an economic farming system.

\section{REFERENCES}

Bahmani, I.; Thom, E.R.; Matthew, C.; Lemaire, G. 2001. Productivity of grazed perennial ryegrass dairy pastures from different ecotypes under nitrogen and irrigation treatments. New Zealand Journal of Agricultural Research 44: 123-133.

Bell, N.L.; King, W.McG.; Rennie, G.M.; Yates, L.J.; Wilson, D.J; Howlett, S.A.; Trolove, M.R. 2009. Best-practice pasture renewal for forage production and sustainability: description of a farmer-led study and initial findings. Proceedings of the New Zealand Grassland Association 71: 155-159.

Bluett, S.J.; Matthew, C.; Bishop-Hurley, G. J.; Haslett, S. J.; Hodgson, J. 1998. The relationship between herbage mass and pasture accumulation rate in winter. New Zealand Journal of Agricultural Research 41: 299-305.

Brougham, R.W. 1957. Pasture growth rate studies in 
relation to grazing management. Proceedings of the New Zealand Society of Animal Production 17: 4655.

Brougham, R.W. 1960. The effects of frequent hard grazings at different times of the year on the productivity and species yield of a grass-clover pasture. New Zealand Journal of Agricultural Research 3: 125-136.

Bryant, A.M. 1990. Optimum stocking and feed management strategies. Proceedings of the Ruakura Farmers' Conference 42: 55-59.

Bryant. A.M.; L'Hullier, P.J. 1986: Better use of pastures. Proceedings of the Ruakura Farmers' Conference 38: 43-51.

Bryant, J.R.; Lambert, M.G.; Brazendale, R.; Holmes, C.W.; Fraser, T.J. 2010a. Effects of intergrated cropping and pasture renewal on the performance and profit of dairy farms. Proceedings of the New Zealand Grassland Association 72: 29-34.

Bryant, J.R.; Ogle, G.; Marshall, P.R.; Glassey C.B.; Lancaster, J.A.S.; Garcia S.C.: Holmes C.W. 2010b. Description and evaluation of the Farmax Dairy Pro decision support model. New Zealand Journal of Agricultural Research 53: 14-31.

Campbell, B.D.; Wardle, D.A.; Woods, P.W.; Field, T.R.O., Williamson, D.Y.; Marker, G.M. 1996. Ecology of subtropical grasses in temperate pastures: an overview. Proceedings of the New Zealand Grassland Association 57: 189-197.

Casal, J.J.; Sanchex, R.A.; Deregibus, V.A. 1987. Tillering response of Lolium multiflorum plants to changes of red/far-red ratio typical of sparse canopies. Journal of Experimental Botany 38: 1432-1439.

Clark, C.E.F.; McLeod, K.L.M.; Glassey, C.B.; Gregorini, P.; Costall, D.A.; Betteridge, K.; Jago, J.G. 2010. Capturing urine while maintaining pasture intake, milk production, and animal welfare of dairy cows in early and late lactation. Journal of Dairy Science 93: 2280-2286.

Da Silva, S.C.; Hodgson, J.; Matthew, C.; Matthews, P.N.P.; Holmes C.W. 2004. Herbage production and animal performance on perennial ryegrass/white clover dairy pastures under alternative spring grazing managements. Journal of Agricultural Science (Cambridge) 142: 97-108.

DairyNZ. 2010. DairyNZ Economic Survey, 2008-09.

Davies, A. 1988. The regrowth of grass swards. pp. 85-127. In: Jones, M.B.; Lazenby, A. eds. The grass crop. London: Chapman and Hall.

Donaghy, D.J.; Turner, L.R.; Adamczewski, K.A. 2008. Effect of defoliation management on water-soluble carbohydrate energy reserves, dry matter yields, and herbage quality of tall fescue. Agronomy Journal 100: 122-127.
Edgecombe, G.A. 1988. The establishment of new pastures on a Waikato dairy farm. Proceedings of the New Zealand Grassland Association.49: 171-176.

Fulkerson, W.J.; Donaghy, D.J. 2001. Plant-soluble carbohydrate reserves and senescence - key criteria for developing an effective grazing management system for ryegrass-based pastures: a review. Australian Journal of Production Agriculture 41: 261-275.

Glassey, C.B. 2007. Development and testing of new performance measures for milksolids production per hectare. Proceedings of the New Zealand Grassland Association 69: 253-257.

Hedley, P.; Kolver, E.; Glassey, C.; Thorrold, B.; Van Bysterveldt, A.; Roche, J.; Macdonald, K. 2006. Achieving high performance from a range of farm systems. pp. 147-166. In: Proceedings of the $4^{\text {th }}$ Dairy ${ }^{3}$ Conference.

Hernández Garay, A.; Matthew, C.; Hodgson, J. 1999. Tiller size/density compensation in perennial ryegrass miniature swards subject to differing defoliation heights and a proposed productivity index. Grass and Forage Science 54: 347-356.

Holmes, C.W. 1989. Increases in milk production per cow and per hectare. How changes in production have been achieved in the past and implications for the future. Dairy Farming Annual 41: 71-76.

Holmes, C.W. 2007. What are the key issues for profitable dairy production? Pasture harvested per hectare and feed conversion efficiency. pp. 3-12. In: Proceedings of the $5^{\text {th }}$ Dairy ${ }^{3}$ Conference.

IPCC. 2010. Frequently asked question 10.1 Are extreme events, like heat waves, droughts or floods, expected to change as the earth's climate changes? Accessed December 2010. http://www.ipcc.ch/ publications_and_data/ar4/wg1/en/faq-10-1.html.

Kay, S.; Harper, J.L. 1974. The regulation of plant and tiller density in a grass sward. Journal of Ecology 62: 97-105.

Lane, P.M.S.; Addison, P.J.; Van Plateringen, M.J. 2009. The Programmed Approach ${ }^{\mathrm{TM}}$ to pasture renewal and cropping. Proceedings of the New Zealand Grassland Association 71: 89-92.

Ledgard, S.F.; Thom, E.R.; Singleton, P.L.; Thorrold, B.S.; Edmeades, D.C. 1996. Environmental impacts on dairy systems. Proceedings of the Ruakura Farmers' Conference 48: 26-33.

Lee, J.M.; Donaghy, D.J.; Roche, J.R. 2008. Effect of defoliation severity on regrowth and nutritive value of perennial ryegrass (Lolium perenne L.) dominant swards. Agronomy Journal 100: 308-314.

L'Hullier, P.J.; Aislabie, D.W. 1988. Natural reseeding in perennial ryegrass/white clover dairy pastures. Proceedings of the New Zealand Grassland Association 49: 111-115. 
LIC 1980. Dairy Statistics 1979/1980. Livestock Improvement Corporation Ltd, Hamilton, New Zealand.

LIC 2010. Dairy Statistics 2009/2010. Livestock Improvement Corporation Ltd, Hamilton, New Zealand.

Macdonald, K.A. 1999. Determining how to make inputs increase your EFS. Proceedings of the Ruakura Dairy Farmers' Conference 51: 78-87.

Macdonald, K.A.; Penno, J.W. 1998. Management decision rules to optimise production on dairy farms. Proceedings of the New Zealand Society of Animal Production 58: 132-135.

Macdonald, K.; Hedley P. 2010a. Stocking the farm to maximise profit and how to manage the risks. Proceedings of the South Island Dairy Event 12: 155173.

Macdonald, K.; Hedley, P. 2010b. Weathering the future. Occasional publication DairyNZ. Farmers' Forum. pp. 39-50.

Macdonald, K.A.; Verkerk, G.A.; Thorrold, B.S.; Pryce, J.E.; Penno, J.W.; McNaughton, L.R.; Burton, L.J.; Lancaster, J.A.S.; Williamson, J.H.; and Holmes C.W. 2008a: A comparison of three strains of Holstein-Friesian grazed on pasture and managed under different feed allowances. Journal of Dairy Science 91: 1693-1707.

Macdonald, K.A.; Penno, J.W.; Lancaster, J.A.S.; Roche, J.R. 2008b. Effect of stocking rate on pasture production, milk production, and reproduction of dairy cows in pasture-based systems. Journal of Dairy Science 91: 2151-2163.

Matthew, C.; Assuero, S.G.; Black, C.K.; Sackville Hamilton, N.R. 2000. Tiller dynamics in grazed swards. pp. 127-150. In: Lemaire, G., Hodgson, J., De Moraes, A., Nabinger, C., Carvalho, F. Eds. Grassland ecophysiology and grazing ecology. CAB International, Wallingford.

Matthew, C.; Hernandez-Garay, A.; Hodgson, J. 1996. Making sense of the link between tiller density and pasture production. Proceedings of the New Zealand Grassland Association 57: 83-87.

Matthew, C.; Sackville Hamilton, N.R. 2011. Analysing persistence of grass swards in terms of tiller birth and death. Pasture persistence. Grassland Research and Practice Series 15: 63-68.

Matthew, C.; Lemaire, G.; Sackville Hamilton, N.R.; Hernandez-Garay, A.G. 1995. A modified size/density equation to describe size/density relationships for defoliated swards. Annals of Botany 76: 579-589.

McGrath, D.F.; Dawson, J.E.; Thomson, N.A.; Simons, H.P. 1998. More Summer Milk - The Opportunities Identified. Proceedings of the Ruakura Farmers' Conference 50: 85-94.
Mitchell, K.J. 1956. Growth of pasture species under controlled environment 1 . Growth at various levels of constant temperature. New Zealand Journal of Science and Technology 38: 203-216.

Montgomerie. W. 2010. AEU Extension, Feeding high BW cows. Accessed 12 December 2010. http:// www.aeu.org.nz/page.cfm?id $=4 \&$ eid $=10$

Musgrave, D.J. 2011. Non-ryegrass pastures - the science and the farmer practice. Pasture persistence. Grassland Research and Practice Series 15: 163-167.

Musgrave, D.J.; Daly, M.J. 2004. Assessment of the performance of non-ryegrass pasture mixtures. Proceedings of the New Zealand Grassland Association 66: 279-283.

Panetta, N.S.; Wardle, D.A. 1992. Gap size and regeneration in New Zealand dairy pasture. Australian Journal of Ecology 17: 169-175.

Parsons, A.J.; Edwards, G.R.; Newton, P.C.D.; Chapman, D.F.; Caradus, J.R.; Rasmussen, S.; Rowarth, J.S. 2010. Past lessons and future prospects: plant breeding for cool temperate pastures. Proceedings of Australasian Dairy Science Symposium 4: 272-291.

Penno, J.W.; Bryant, A.M.; Carter, W.A.; Macdonald, K.A. 1995. Effect of nitrogen fertiliser and summer rotation length on milk production in a dry Waikato summer. Proceedings of the New Zealand Society for Animal Production 55: 64-66.

Popay, A.J.; Thom, E.R. 2009. Endophyte effects on major insect pests in Waikato dairy pasture. Proceedings of the New Zealand Grassland Association 71: 121-126.

Rawnsley, R.P.; Donaghy, D.J.; Fulkerson, W.J.; Lane, P.A. 2002. Changes in the physiology and feed quality of cocksfoot (Dactylis glomerata L.) during regrowth. Grass and Forage Science 57: 203-211.

Rawnsley, R.P.; Donaghy, D.J.; Stevens, D.R. 2007. What is limiting production and consumption of perennial ryegrass in temperate dairy regions of Australia and New Zealand? Meeting the Challenges for Pasture-Based Dairying. Proceedings of the Australasian Dairy Science Symposium 3: 256-274.

Rolston, M.P.; Hare, M.D.; Latch, G.C.M.; Christensen, M.J. 1991. Acremonium endophyte viability in seeds and the effects of storage. Agronomy Society of New Zealand. Special Publication 9: 77-82.

Romera, A.J.; Beukes, P.; Clark, C.; Clark, D.; Levy, H.; Tait, A. 2010. Use of a pasture growth model; to estimate herbage mass at a paddock scale and assist management on dairy farms. Journal of Computers and Electronics in Agriculture 74: 66-72.

Sanderson, K.; Webster, M. 2009. Economic analysis of the value of pasture to the New Zealand economy. Report to the Pasture Renewal Charitable Trust. Accessed 22/12/10. http://www.pasturerenewal.org. 
nz/downloads/economic_analysis\%20of_pasture value_to_nz_economy.pdf

Staines, M.; Morris, R. 2008. Grazing management the forgotten factor with $\mathrm{N}$ fertiliser? Agricultural Memo Department of Agriculture and Food 35 issue 1.

Stewart, A.V. 2006. Genetic origins of perennial ryegrass (Lolium perenne) for New Zealand pastures. pp. 1120. In: 'Breeding for Success: Diversity in Action'. C.F. Mercer (ed). Proceedings of the 13th Australasian Plant Breeding Conference,Christchurch, New Zealand.

Thom, E.R.; Van Vught, V.T.; McCabe, R.J. 1996. Growth and persisitence of perennial ryegrass lines with different tolerances to "pulling" during grazing. Proceedings of the New Zealand Grassland Association 58: 67-72.
Thom, E.R.; Clark, D.A.; Waugh, C.D. 1999. Growth, persistence, and alkaloid levels of endophyte-infected and endophyte-free ryegrass pastures grazed by dairy cows in northern New Zealand. New Zealand Journal of Agricultural Research 42: 241-253.

Woodfield, D.R.; Easton, H.S. 2004. Advances in pasture plant breeding for animal productivity and health. New Zealand Veterinary Journal 52: 310-311. 
